DEPARTMENT OF THE INTERIOR

UNITED STATES GEOLOGICAL SURVEY

GEOLOGIC MAP OF THE GRAYBACK QUADRANGLE, PINAL COUNTY, ARIZONA

By H. R. Cornwall and M. H. Krieger 


\section{GEOLOGIC MAP SYMBOLS}

COMMONLY USED ON MAPS OF THE UNITED STATES GEOLOGICAL SURVEY

(Special symbols are shown in explanation)

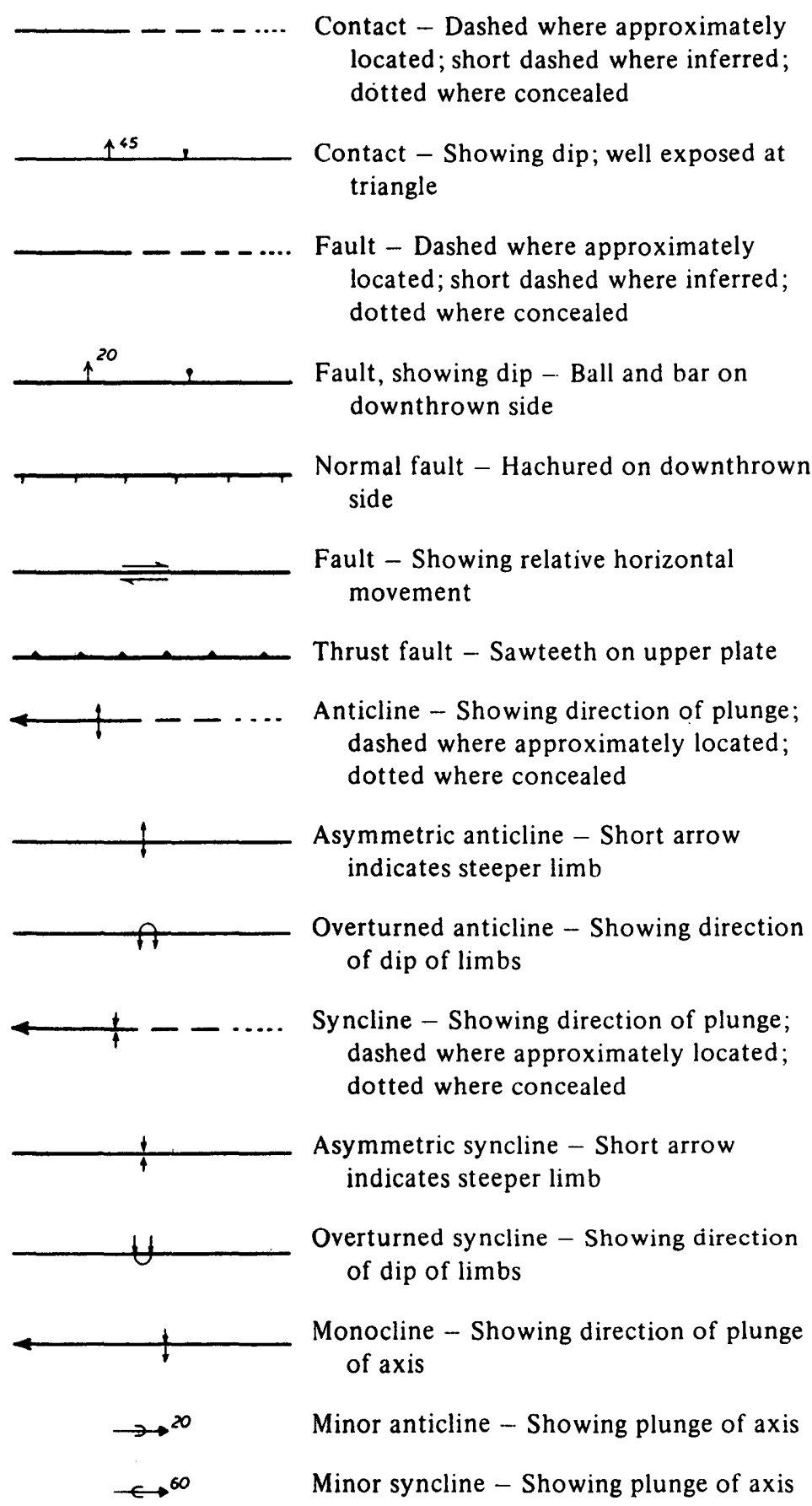

Strike and dip of beds - Ball indicates top of beds known from sedimentary structures

$\stackrel{70}{2}$ Inclined $\oplus$ Horizontal

+ Vertical +40 Overturned

Strike and dip of foliation 20 Inclined $\rightarrow$ Vertical $\nrightarrow$ Horizontal

Strike and dip of cleavage

15 Inclined $\longrightarrow$ Vertical It Horizontal

Bearing and plunge of lineation

${ }^{15} \leftarrow$ Inclined - Vertical $\longleftrightarrow$ Horizontal

Strike and dip of joints

$\ldots$ Inclined $\rightarrow$ Vertical + Horizontal

Note: planar symbols (strike and dip of beds, foliation or schistosity, and cleavage) may be combined with linear symbols to record data observed at same locality by superimposed symbols at point of observation. Coexisting planar sy mbols are shown intersecting at point of observation.

Shafts

$\square$ Vertical $\square$ Inclined

Adit, tunnel, or slope

$\succ$ Accessible ^Inaccessible

$\times$ Prospect

Quarry

x Active Abandoned

Gravel pit

$x$ Active $x$ Abandoned

Oil well

- Drilling $\phi$ Shut-in $\&$ Dry hole

* Gas Show of gas abandoned

- Oil Show of oil 


\title{
GEOLOGIC MAP OF THE GRAYBACK QUADRANGLE, PINAL COUNTY, ARIZONA
}

\author{
By H. R. Cornwall and M. H. Krieger
}

\section{GENERAL GEOLOGY}

The Pinal Schist, of Precambrian $\mathrm{X}$ age, is the oldest formation that crops out in the Grayback quadrangle. The east half of the quadrangle is largely underlain by the Ruin Granite, of early Precambrian Y age, which intruded the Pinal Schist. This intrusive relationship is evident in other, nearby areas, the Sonora quadrangle, for example (Cornwall and others, 1971). The Ruin Granite was intruded by diabase dikes and sills of late Precambrian $Y$ age. The Precambrian rocks have been intruded by the Tortilla Quartz Diorite of Late Cretaceous age and the Tea Cup Granodiorite, a large Paleocene pluton. These two plutons have themselves been intruded by Paleocene and younger Tertiary dikes of andesite, rhyodacite, quartz latite, and rhyolite. On the basis of intrusive relationships, most of the dikes are dated as Paleocene and younger; however, two types (TKmr and TKrh) do not intrude the Tea Cup Granodiorite and may therefore be older than the others. The dikes diminish in number and terminate westward across the quadrangle. Most have east-west trends with steep to vertical dips, but some change trend to northwest in the southeastern quarter of the quadrangle.

The Whitetail Conglomerate, a gently eastward dipping Oligocene conglomerate in the northwest corner of the quadrangle, unconformably overlies older rocks, is cut by younger rhyolite dikes, and is overlain by younger flows. A graben in Ripsey Wash, along the eastern edge of the quadrangle, contains east-dipping conglomerate, sandstone, and tuff. These terrestrial deposits were derived from surrounding highlands as the basin subsided during the early Miocene. In the Quaternary, gravels have been shed westward onto an alluvial plain from the higher, central part of the quadrangle. The Gila River, a major regional stream, flows west across the northern part of the quadrangle and is flanked by older Quaternary gravel terraces.

\section{ECONOMIC GEOLOGY}

A number of fissure zones with limonite, quartz, and, in many places, copper oxides crop out in the east half of the quadrangle. The zones dip steeply, range in strike from east-northeast through east to west-northwest, and transect most of the rocks in the area, including the Ruin Granite, diabase sills and dikes, Tea Cup Granodiorite, Tortilla Quartz Diorite, and rhyodacite dikes. Many of the zones have been explored by pits, trenches, and shafts, and a few by drill holes.
The most intensive exploration has been in secs. 8 and 9 , T. 4 S., R. 13 E., an area where a steeply dipping protrusion of the Tea Cup Granodiorite, roughly 500 feet thick, extends eastward more than half a mile into the Ruin Granite. The deposit indicated on the map by a shaft in the southeast corner of sec. 8, T. 4 S., R. 13 E., is reported to contain copper and molybdenum sulfides. It has been explored by several mining companies. There is abundant chalcocite $\left(\mathrm{Cu}_{2} \mathrm{~S}\right)$ and pyrite $\left(\mathrm{FeS}_{2}\right)$ on dumps near two shafts located 1,600 feet east of the shaft mentioned above. Several limonitic shear zones that extend north of these two shafts for half a mile have been explored by pits and shafts. The Tea Cup Granodiorite in secs. 7 and 18, T. 4 S., R. 13 E., contains widespread disseminated malachite, chrysocolla, and limonite, indicating the original presence of copper and iron sulfides.

The Golden Bell mine in the NE1/4 sec. 7, T. 4 S., R. 13 E., explored northeast-trending, steeply dipping fissure zones, 1-5 feet thick, that on the surface contain chrysocolla, malachite, limonite, and quartz. The Wooley mine in the $\mathrm{N} 1 / 2$ sec. 33, T. 4 S., R. 13 E., consists of a shaft, adit, and opencuts that explored a steeply dipping east-west-trending fissure and breccia zone half a mile long and 50-200 feet wide. Outcrops of the zone contain disseminated chrysocolla, malachite, limonite, and quartz. A shaft and several pits explore two east-trending, vertical shear zones in the $\mathrm{SW}^{1 / 4} \mathrm{sec} .30$ and NW1/4 sec. $31, \mathrm{~T} .4 \mathrm{~S}$., R. 13 E. These zones contain 1- to 5-foot veins of quartz with chrysocolla, malachite, and limonite. Pits, trenches, and a diamond drill hole in the SE1/4 sec. 10, T. 5 S., R. 13 E., explore fissure zones containing malachite, chrysocolla, and limonite.

The deposits described above are the most notable ones explored in the quadrangle. Copper and molybdenum were the principal metals found. Other mineralized areas are indicated on the map by additional fissure zones and exploration pits and trenches. There is no recorded production of copper or other metals from this quadrangle.

\section{REFERENCES CITED}

Banks, N. G., Cornwall, H. R., Silberman, M. L., Creasey, S. C., and Marvin, R. F., 1972, Chronology of intrusion and ore deposition at Ray, Arizona-Part I, K-Ar ages: Econ. Geology, v. 67, p. 864-878.

Banks, N. G., and Stuckless, J. S., 1973, Chronology of intrusion and ore deposition at Ray, Arizona-Part II, Fission-track ages: Econ. Geology, v. 68, p. 657-664. 
Cornwall, H. R., Banks, N. G., and Phillips, C. H., 1971, Geologic map of the Sonora quadrangle, Pinal and Gila Counties, Arizona: U.S. Geol. Survey Geol. Quad. Map GQ-1021, scale $1: 24,000$.

Cornwall, H. R., and Krieger, M. H., 1975, Geologic map of the Kearny quadrangle, Pinal County, Arizona: U.S. Geol. Survey Geol. Quad. map GQ-1188, scale 1:24,000, (in press).

Damon, P. E., 1970, New K-Ar dates for the southern Basin and Range Province, in Annual progress reports to Research Division: U.S. Atomic Energy Comm., June 1970, p. 38.

Heindl, L. A., 1963, Cenozoic geology in the Mammoth area, Pinal County, Arizona: U.S. Geol. Survey Bull. 1141-E, p. El-E41.

Krieger, M. H., 1974a, Generalized geology and interpretation of structure of the Winkelman 15-minute quadrangle and vicin- ity, Pinal and Gila Counties, Arizona: U.S. Geol. Survey Jour. Research, v. 2, no. 3. p. 311-321.

1974b, Geologic map of the Winkelman quadrangle, Pinal and Gila Counties, Arizona: U.S. Geol. Survey Geol. Quad. Map GQ-1106, scale 1:24,000 (in press).

1974c, Geologic map of the Crozier Peak quadrangle, Pinal County, Arizona: U.S. Geol. Survey Geol. Quad. Map GQ-1 107, scale 1:24,000 (in press).

1974d, Geologic map of the Putnam Wash quadrangle. Pinal County, Arizona: U.S. Geol. Survey Geol. Quad. Map GQ-1109, scale 1:24,000 (in press).

Krieger, M. H., Cornwall, H. R., and Banks, N. G., 1974, The Big Dome Formation and revised Tertiary stratigraphy in the Ray-San Manuel area, Arizona, in Contributions to stratigraphy: U.S. Geol. Survey Bull. 1394-A, p. 54-62. 